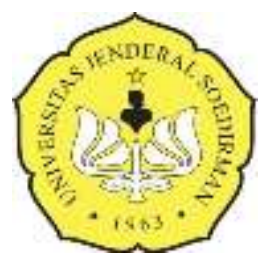

PAJU Volume 1 Nomor 12019

PHYSICAL ACTIVITY JOURNAL

http://jos.unsoed.ac.id/index.php/paju

\title{
Identifikasi Kebugaran Jasmani Siswa SMP Di Daerah Dataran Tinggi Kabupaten Banyumas
}

\author{
Topo Suhartoyoㄹ, Didik Rilastiyo Budi², Moh. Nanang Himawan Kusuma3 ${ }^{3}$, Muhamad Syafei ${ }^{4}$, Arfin Deri \\ Listiandi 5 , Rohman Hidayat ${ }^{6}$ \\ 1,2,3,4,5,6 Fakultas IImu-IImu Kesehatan, Universitas Jenderal Soedirman, Indonesia \\ email: topo suhrtoyo@yahoo.com¹ , didikrilastiyobudi@yahoo.co.id² , anangkusuma@yahoo.com³ \\ fisalmaulana@yahoo.com ${ }^{4}$, arfinderilistiandi@gmail.com ${ }^{5}$, hidayatrohman100789@gmai.com 6 \\ DOI: https://doi.org/10.20884/1.paju.2019.1.1.1995
}

\begin{abstract}
Abstrak
Kebugaran jasmani merupakan salah satu faktor penting bagi siswa untuk dapat melakukan bebagai aktifitas fisik dan oalhraga, selain itu kebugaran jasmani yang baik juga dapat memberikan dampak positif terhadap perkembangan prestasi siswa, baik secara kognitif, afektif maupun psikomotor. Tujuan penelitian untuk mengetahui profil kebugaran jasmani siswa SMP di dataran tinggi Kabupaten Banyumas, khususnya di daerah Kedungbanteng dan Baturraden. Metode penelitian studi deskriptif ex-postfacto. Instrumen penelitian menggunakan Multilevel Fitnes Test (MFT) untuk mengukur kebugaran jasmani. Analisis data menggunakan Uji Normalitas dan Penilaian Acuan Norma (PAN). Hasil penelitian menunjukan bahwa siswa putra SMP di daerah Kedungbanteng dan Baturraden masih banyak yang berada di tingkat kebugaran cukup dan kurang dengan jumlah 45 anak atau sebesar $90 \%$, sedangkan tingkat kebugaran jasmani siswa putri menunjukan hasil 48 siswa atau $98 \%$ berada dikategori kebugaran jasmani cukup dan kurang. Kesimpulan penelitian ini siswa SMP di dataran tinggi memiliki tingkat kebugaran yang kurang, sehingga perlu adanya program khusus yang memicu siswa SMP untuk melakukan berbagai aktifitas fisik dan olahraga.
\end{abstract}

Kata Kunci : Kebugaran Jasmani, Siswa SMP, Dataran Tinggi, Kabupaten Banyumas

\begin{abstract}
Physical fitness is an important factor for students to be able to do various physical and sports activities, besides that good physical fitness can also have a positive impact on the development of student achievement, both cognitive, affective and psychomotor. The purpose of this study was to determine the physical fitness profile of junior high school students in the highlands of Banyumas Regency, especially in the Kedungbanteng and Baturraden areas. The research method is an ex-postfacto descriptive study. The research instrument used the Multilevel Fitness Test (MFT) to measure physical fitness. Data analysis using the Normality Test and Norm Reference. The results showed that there are still many male junior high school students in the Kedungbanteng and Baturraden areas that are in sufficient and insufficient fitness levels with 45 children or $90 \%$, while the physical fitness level of female students shows the results of 48 students or $98 \%$ are in the sufficient physical fitness category and less. The conclusion of this study is that junior high school students in the highlands have a lack of fitness, so there is a need for a special program that triggers junior high school students to do various physical and sports activities.
\end{abstract}

Keywords: Physical Fitness, Middle School Students, Highlands, Banyumas Regency 
Topo Suhartoyo1 ${ }^{1}$, Didik Rilastiyo Budi2, Moh. Nanang Himawan Kusuma ${ }^{3}$, Muhamad Syafei ${ }^{4}$, Arfin Deri Listiandi ${ }^{5}$, Rohman Hidayat6 / PAJU : Physical Activity Journal 1 (1) (2019)

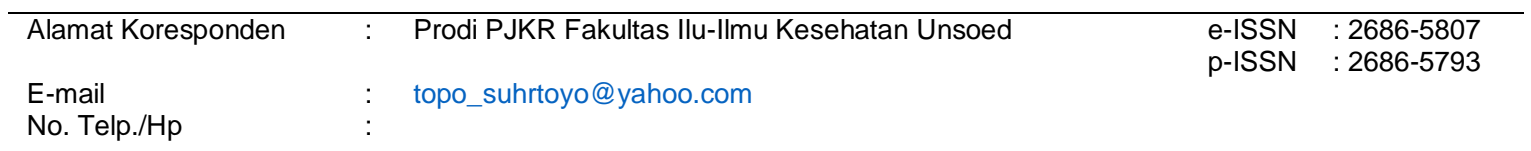

\section{PENDAHULUAN}

Kebugaran jasmani tidak hanya dibutuhkan oleh atlet-atlet olahraga, akan tetapi juga dibutuhkan oleh semua orang untuk dapat melaksanakan tuntutan tugas fisik setiap harinya. Secara umum kebugaran jasmani dapat didefinisikan sebagai kemampuan tubuh untuk melakukan berbagai aktifitas fisik tanpa mengalami kelelahan berlebihan, dan tetap merasa bugar pada keesokan harinya untuk melakukan tugas fisik berikutnya. Kebugaran jasmani atau Physical Fitness dapat diterjemahkan dalam istilah-istilah lain misalnya: kesegaran jasmani, kesanggupan jasmani dan kesamaptaan jasmani. Secara harfiah arti Physical Fitness ialah kecocokan fisik atau kesesuaian jasmani. Tetapi Fit juga dapat berarti sehat, sehingga Fitness dapat berarti kesehatan atau dapat diartikan sebagai kecocokan fisik atau kesesuaian jasmani (Giriwijoyo, 2012).

Sejalan dengan pendapat di atas, (Budi, 2015) menjelaskan bahwa Kebugaran jasmani merupakan aspek penting dari domain psikomotorik, yang bertumpu pada perkembangan kemampuan biologis organ tubuh. Konsentrasinya lebih banyak pada persoalan peningkatan efisiensi fungsi faal tubuh dengan segala aspeknya sebagai sebuah sistem (misalnya sistem peredaran darah, sistem pernapasan, sistem metabolisme, dan lain-lain). Anak-anak pada tahap pertumbuhan dan perkembangan baik secara fisik, keterampilan dan psikologis memerlukan tingkat kebugaran jasmani yang sesuai dengan umurnya masingmasing untuk dapat melaksanakan tuntutan tugas gerak sehari-hari dan olahraga dengan baik. Hasil penelitian menunjukan bahwa Siswa dengan kebugaran jasmani tinggi pada kelompok pembelajaran permainan vobas memiliki tingkat kerjasama yang lebih baik (Budi, 2015).

Kebugaran jasmani tidak hanya memberikan pengaruh yang baik terhadap perkembangan aspek afektif pada siswa, akan tetapi dengan kebugaran jasmani yang baik juga akan mampu memberikan pengaruh terhadap hasil belajar. Siswa yang memiliki tingkat kebugaran jasmani tinggi akan mendapat hasil prestasi akademik yang tinggi juga (Hidayat, 2015).

Hasil belajar yang dimaksud dalam pendidikan jasmani mencakup tiga aspek yaitu kognitif, afektif dan psikomotor (Budi et al., 2019). Siswa SMP secara pertumbuhan dan perkembangan merupakan fase yang penting untuk meningkatkan kebugaran jasmani sebagai salah satu faktor penting untuk memperoleh prestasi belajar yang baik, sehingga ranah kognitif, afektif dan psikomotor dapat berkembang secara maksimal. (Wirnantika, Pratama, \& Hanief, 2017) menjelaskan bahwa Kebugaran jasmani akan mengantarkan anak didik menuju kesiapan jasmani, mental dan emosional, kematangan psikologis dan fisik, serta mengantarkan anak untuk semangat belajar dan berlatih sehingga akan tercapai prestasi belajar yang diharapkan

Pada perkembangannya, sebagian besar siswa SMP tidak lagi menganggap bahwa aktifitas fisik dan kebugaran jasmani merupakan kebutuhan yang penting bagi mereka, ktivitas siswa SMP sekarang lebih 
banyak dihabiskan dengan aktifitas pasif. (Kusuma, Muhamad, \& Rilastiyo, 2019) menjelaskan bahwa Perkembangan teknologi komunikasi dan transportasi mengakibatkan perubahan sifat dasar alamiah manusia yang aktif bergerak tergantikan oleh aktivitas pasif dan kurang gerak.

Siswa SMP yang memiliki kekurangan gerak, dalam hal ini aktivitas fisik olahraga akan mengakibatkan tidak hanya penurunan kebugaran jasmani saja akan tetapi juga dapat memicu penyakit hipokinetik (kurang gerak). Penyakit hipokinetik merupakan salah satu penyakit yang berhubungan dengan kurangnya aktivitas gerak atau berolahraga (inacitvity) (Kusuma et al., 2019) Pergeseran kebiasaan dari aktif menjadi pasif olahraga pada siswa SMP tidak hanya terjadi di kota-kota besar, akan tetapi juga mulai berdampak kepada siswa SMP di daerah pedesaan dan dataran tinggi. (Kusuma et al., 2019) menjelaskan bahwa sebagian besar penduduk Indonesia (85\%) masih belum sadar akan pentingnya aktivitas fisik dan hanya sekitar $15 \%$ dari penduduk di Indonesia yang sadar akan pentingnya aktivitas fisik.

Dilihat dari segi geografis, anak-anak di lingkungan pedesaan dan pegunungan sehrusnya memiliki tingkat kebugaran jsmanai yang lebih baik dibandingkan dengan anak-anak di daerah perkotaan. Akan tetapi pada kenyataan di lapang tidak terjadi demikian, anak-anak di pedesaan dan pegunungan juga kurang memiliki tingkat kebugaran jasmani yang baik. Hasil penelitian menunjukan bahwa kebugaran jasmani siswa kelas IV Sekolah Dasar Puhrubuh I dan MI Mambaul Hikam Kecamatan Semen Kabupaten Kediri Tahun Pelajaran 2016/2017 dalam kategori sedang (Wirnantika et al., 2017), kedua sekolah tersebut termasuk kedalah wilayah pedesaan.

Kabupaten Banyumas merupakan salah satu daerah yang sedang berkembang, sehingga masih memiliki banyak wilayah pedesaan dan dataran tinggi pegunungan. Potensi pengembangan olahraga di daerah kabupaten Banyumas sudah berjalan cukup baik, hal ini ditunjukan dengan sudah terdapat beberapa kelas olahraga di jenjang SMP dan SMA, sehingg diharapkan pola pembinaan olahraga utuk anak-anak sekolah dapat berjalan dengan baik.

Pembinaan olahraga di lingkungan sekolah dapat dilaksanakn apabila terdapat evaluasi mengenai berbgai hal, salah satunya yaitu tingkat kebugaran jasmani siswa yang terdapat di sekolah tersebut. Selama ini belum pernah dilakukan penelitian mengenai profil kebugaran jasmani siswa SMP di Kabupaten Banyumas,, khususnya di wilayah dataran tinggi/pegunungan. Untuk mengetahui profil kebugaran jasmani siswa SMP di daerah pegunungan perlu dilakukan penelitian melalui tes kebugaran jasmani, sehingga akan terlihat profil kebugaran jasmani siswa SMP di wilayah pegunungan/dataran tinggi Kabupaten Banyumas. Data penelitian ini sangat penting untuk mengukur keberhasilan pola pembinaan olahraga di daerah dan juga untuk mengetahu apakah siswa SMP memiliki waktu yang cukup banyak dalam melakukan aktifitas olahraga, baik di sekolah maupun di lingkungan tempat tinggalnya.

\section{METODE}

Penelitian ini menggunakan metode deskriptif, karena penulis berpendapat bahwa metode ini paling tepat untuk diterapkan dalam penelitian ini. Dalam penelitian ini, data yang diperoleh dikumpulkan, disusun, 
dijelaskan, dan dianalisis untuk menetapkan kesimpulan. Hal ini untuk memperoleh gambaran yang jelas sehingga tujuan penelitian tercapai seperti yang diharapkan. Oleh karena itu metode yang digunakan dalam penelitian ini adalah metode deskriptif ex-postfacto. Mengenai metode ini, (Sugiyono, 2015) menjelaskan bahwa penelitian ex postfacto merupakan suatu penelitian yang dilakukan untuk meneliti suatu peristiwa yang telah terjadi dan kemudian melihat ke belakang untuk mengetahui faktor-faktor yang dapat menimbulkan kejadian tersebut.

Populasi penelitian ini yaitu seluruh siswa SMP di Kabupaten Banyumas yang berada di wilayah dataran tinggi atau pegunungan. Sampel penelitian yaitu siswa SMP Negeri kelas VIII yangberda di wilayah Baturraden dan Kedungbanteng. Untuk memilih sampel penulis menggunakan teknik Cluster Random Sampling. (Maksum, 2012) menjelaskan bahwa, "Dalam cluster random sampling, yang dipilih bukan individu melainkan kelompok atau area yang kemudian disebut cluster." Misalnya propinsi, kabupaten/kota, kecamatan, dan sebagainya. Bisa juga dalam bentuk kelas dan sekolah. Sampel pada penelitian ini yaitu siswa kelas VII di sekolah SMPN 1 Baturraden, SMPN 2 Baturraden, SMPN 1 Kedungbanteng dan SMPN 4 Kedungbanteng, semua sekolah tersebut berada di wilayah pegunungan/dataran tinggi.

Penulis menggunakan instrument pengumpulan data, yaitu Untuk mengukur tingkat kebugaran jasmani menggunakan Multilevel Fitnes Test (MFT) yang dilakukan di Sekolah Menengah Pertama (SMP) pada wilayah Kedungbanteng dan Baturraden. Prosedur tes MFT yaitu ssiwa melakukan lari bolak balik sejauh 20 meter dengan cara mengikuti irama atau suara dari perangkat tes MFT. Kriteria untuk menghentikan testi apabila testi tetinggal tanda bunyi "tuut" dua kali lebih dari dua langkah di belakang garis ujung.

Analisis data menggunakan perhitungan normalitas menggunakan SPSS. Penilaian Acuan Norma (PAN) untuk melihat tingkat kebugaran jasmani melalui tes MFT. Norma Tes MFT untuk sisw SMP dengan rerata umur 14 tahun adalah sebagi berikut:

Tabel 1. Norma Klasifikasi Tingkat VO2Max (Ariansyah, 2017)

\begin{tabular}{lccccc}
\hline \multicolumn{1}{c}{ Jenis Kelamin } & Usia & Very Poor & Poor & Fair & Good \\
\hline Laki-Laki & $13-19$ & $<25.0$ & $25.0-30.9$ & $31.0-34.9$ & $35.0-38.9$ \\
\hline Perempuan & $13-19$ & $<35.0$ & $35.0-38.3$ & $38.4-45.1$ & $45.2-50.9$
\end{tabular}

\section{HASIL}

\section{Uji Normalitas Data}

Uji normalitas data digunakan untuk mengetahui apakah sebaran data kebugaran jasmani siswa di setiap sekolah dataran tinggi/pegunungan Kabupaten Banyumas. Data normalitas kebugaran jasmani dihitung dengan menggunakan SPSS Sapiro wilk dengan tingkat signifikansi 0,05. Data dikatakan berdistribusi normal apabila nilai sig. > dari 0,05 , hasil sebagai berikut: 
Topo Suhartoyo ${ }^{1}$, Didik Rilastiyo Budi², Moh. Nanang Himawan Kusuma ${ }^{3}$, Muhamad Syafei ${ }^{4}$, Arfin Deri Listiandi 5 , Rohman Hidayat ${ }^{6}$ / PAJU : Physical Activity Journal 1 (1) (2019)

Tabel 2. Uji Normalitas Data

\begin{tabular}{lcl}
\hline \multicolumn{1}{c}{ Sampel } & Normalitas (Sig) & Keterangan \\
\hline Siswa Putra SMPN 1 Kedungbanteng & 0.317 & Normal \\
\hline Siswa Putri SMPN 1 Kedungbanteng & 0.829 & Normal \\
\hline Siswa Putra SMPN 4 Kedungbanteng & 0.912 & Normal \\
\hline Siswa Putri SMPN 4 Kedungbanteng & 0.615 & Normal \\
\hline Siswa putra SMPN 1 Baturraden & 0.942 & Normal \\
\hline Siswa putri SMPN 1 Baturraden & 0.933 & Normal \\
\hline Siswa putra SMPN 2 Baturraden & 0.917 & Normal \\
\hline Siswa putri SMPN 2 Baturraden & 0.996 & Normal \\
\hline
\end{tabular}

Berdasarkan hasil olah data tersebut maka dapat diketahui bahwa seluruh data kebugaran jasmani siswa SMP di dataran tinggi/pegunungan kabupaten Banyumas berdistribusi normal karena nila signifikansi data lebih besar dari 0,05 .

\section{Data Kebugaran Jasmani Siswa SMP}

Hasil tingkat kebugaran jasamani siswa putra SMP di daerah dataran tinggi/pegunungan Kabupaten Banyumas (Kedungbanteng dan Baturraden) dapat di lihat pada tabel 2 dan gambar 1 berikut ini

Tabel 3. Tingkat Kebugaran Jasmani Siswa SMP Putra di Dataran Tinggi

\begin{tabular}{lc}
\hline \multicolumn{1}{c}{ Kategori } & Jumlah Siswa \\
\hline Baik & 5 \\
\hline Cukup & 16 \\
\hline Kurang & 29 \\
\hline
\end{tabular}

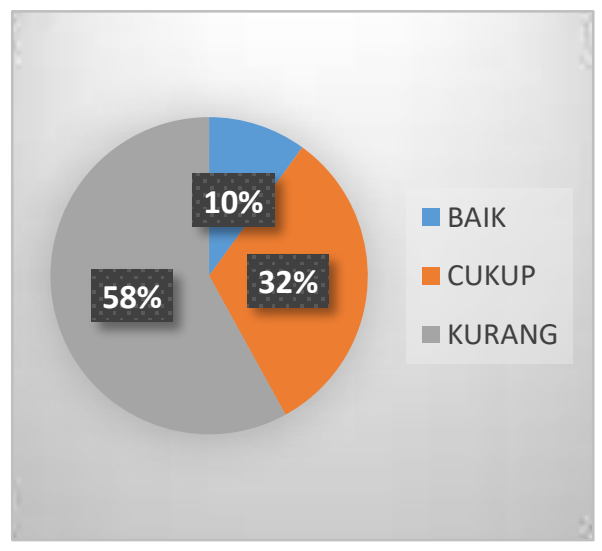

Gambar 1 Tingkat Kebugaran Jasmani Siswa Putra SMP 
Berdasarkan tabel dan gambar di atas dapat disimpulkan bahwa tingkat kebugaran jasamani siswa putra SMP di dataran tinggi/pegunungan Kabupaten Banyumas, khususnya di daerah Kedungbanteng dan Baturraden dari jumlah sampel 50 orang, didapatkan hasil jumlah siswa putra dengan kategori kebugaran jasmani baik yaitu sebanyak 5 orang atau sebesar 10\%, kebugaran jasmani Cukup sebanyak 16 orang atau sebesar $32 \%$ dan kaebugaran jasmani kurang sebanyak 29 orang atau sebesar $58 \%$.

Kebugaran jasmani siswa putri SMP di daerah dataran tinggi/pegunungan Kabupaten Banyumas (Kedungbanteng dan Baturraden) dapat di lihat pada tabel 3 dan gambar 2 berikut ini

Tabel 4. Tingkat Kebugaran Jasmani Siswa SMP Putri di Dataran Tinggi

\begin{tabular}{lc}
\hline \multicolumn{1}{c}{ Kategori } & Jumlah Siswa \\
\hline Baik & 2 \\
\hline Cukup & 19 \\
\hline Kurang & 29 \\
\hline
\end{tabular}

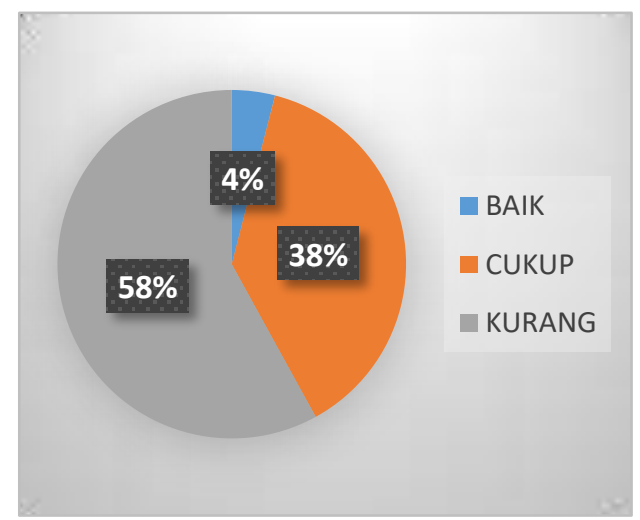

Gambar 2 Tingkat Kebugaran Jasmani Siswa Putri SMP

Berdasarkan tabel dan gambar di atas dapat disimpulkan bahwa tingkat kebugaran jasamani siswa putri SMP di dataran tinggi/pegunungan Kabupaten Banyumas, khususnya di daerah Kedungbanteng dan Baturraden dari jumlah sampel 50 orang, didapatkan hasil jumlah siswa putri dengan kategori kebugaran jasmani baik yaitu sebanyak 2 orang atau sebesar 4\%, kebugaran jasmani Cukup sebanyak 19 orang atau sebesar 38\% dan kaebugaran jasmani kurang sebanyak 29 orang atau sebesar $58 \%$.

Perbandingan tingkat kebugaran jasmani siswa putra dan putri di daerah Kedungbanteng dan Baturraden Kabupaten Banyumas dapat dilihat di tabel 4 dan gambar 3 di bawah ini

Tabel 5. Perbandingan Nilai Rata-Rata Tingkat Kebugaran Jasmani Siswa Putra dan Putri

\begin{tabular}{lcc}
\hline \multicolumn{1}{c}{ Jenis Kelamin } & Jumlah Rata-Rata & Kategori Kebugaran \\
\hline Laki-laki & 38,46 & Cukup \\
\hline Perempuan & 30,53 & Kurang \\
\hline
\end{tabular}




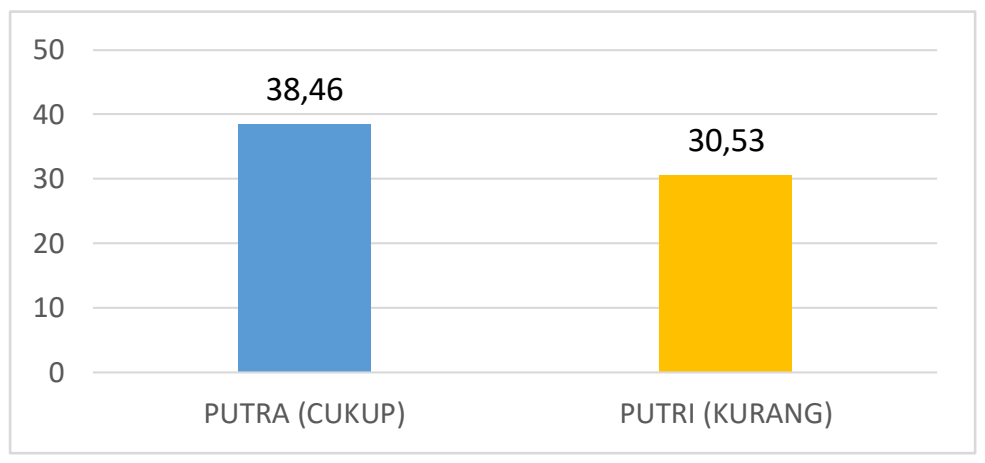

Gambar 3. Nila Rata-Rata Kebugaran Jasmani Siswa Putra dan Putri

Berdasarkan data tersebut dapat disimpulkan bahwa nilai rata-rata kebugaran jasmani siswa putra sebesar 38,46 atau dalam katagori cukup baik, sedangkan siswa petri sebesar 30,53 atau dalam kategori kurang, sehingga dari data tersebut siswa putra memiliki tingkat kebugaran jasmani yang lebih baik daripada siswa putri di daerah Kedungbanteng dan Baturraden.

\section{PEMBAHASAN}

Hasil kebugaran jasmani menunjukan bahwa siswa putra SMP di daerah Kedungbanteng dan Baturraden masih banyak yang berada di tingkat kebugaran cukup dan kurang dengan jumlah 45 anak atau sebesar $90 \%$, sedangkan tingkat kebugaran jasmani siswa putri menunjukan hasil 48 siswa atau $98 \%$ berada dikategori kebugaran jasmani cukup dan kurang dari jumlah sampel penelitian, hal ini menunjukan bahwa tingkat aktifitas fisik anak di daerah tersebut masih rendah sehingga mempengaruhi kebugaran jasmani yang mereka miliki. (Safaringga \& Herpandika, 2018) menjelaskan bahwa Semakin banyak aktivitas fisik yang dilakukan maka tingkat kebugaran jasmaninya akan semakin tinggi. Berdasarkan hasil penelitian terdahulu maka tingkat aktifitas fisik pada anak sangat berpengaruh dengan tingkat kebugaran jasmani yang dimiliki. Penurunan sekresi eritropoietin disebabkan kurangnya aktivitas fisik, sehingga produksi hemoglobin akan menurun yang mana berfungsi sebagai pemasok oksigen, dengan kata lain, semakin aktif seseorang dalam aktivitas fisik atau berolahraga maka semakin meningkat pula Kadar hemoglobinnya (Kusuma et al., 2019).

Selian hasil tersebut, dalam penelitian ini juga diperoleh data bahwa rata-rata kebugaran jasmani siswa putra lebih baik daripada kebugaran siswa putri di daerah dataran tinggi Kabupaten Banyumas, dengan hasil 38,46 untuk putra atau dalam kategori kebugaran jasmani cukup dan 30,53 untuk putri atau berada dalam kategori kebugaran jasamni kurang. Data tersebut menunjukan bahwa secara keseluruhan tingkat kebugaan jasmani yang dimiliki oleh siswa SMP putra dan putri di daerah dataran tinggi Kabupaten Banyumas harus ditingkatkan, karena kebugaran jasmani merupakan salah satu foktor penting dalam perkembangan anak baik secara kognitif, afektif maupun psikomotor. (Budi, 2015) menjelaskan bahwa siswa dapat melakukan berbagai aktivitas belajar di sekolah maupun di masyarakat apabila mereka memilik kondisi tubuh dan kebugaran yang baik, sehingga dalam proses belajarnya siswa dapat mengembangkan potensi yang ada pada dirinya. Lebih lanjut mengenai pentingnya kebugaran jasmani, (Wirnantika et al., 2017) 
menjelaskan Kebugaran jasmani siswa yang baik akan menjamin kesiapan siswa dalam melaksanakkan tugas sehari-hari dan selalu menapakkan penampilan yang optimal.

Rendahnya tingkat kebugaran jasmani yang dimiliki oleh siswa SMP di daerah Kedungbanteng dan Baturraden kabupaten Banyumas menunjukan adanya pergeseran kebiasaan yang dilakukan oleh anakanak. Secara alamiah, anak-anak berada pada fase bagaimana mereka mampu mengembangkan diri melalui berbagai aktifitas fisik dan permainan, sehingga mereka mampu mengembangakan berbagai aspek di dalam diri, akan tetapi dengan kemajuan jaman dan teknologi kebiasaan tersebut sekarang mulai berganti dengan berbagai aktifitas yang pasif dan instans dan apabila dikaji lebih dalam dapat menganggu perkambangan potensi anak.

Kebugaran jasmani pada siswa SMP dapat ditingkatkan dengan memberikan aktifitas fisik yang sesuai kepada siswa di sekolah dan di lingkungan tempat tinggal sehingga siswa memiliki kegembiraan pada saat melakukan aktifikas fisik sehingga siswa memiliki motivasi tinggi untuk bergerak aktif dalam kesehariannya. Aktifitas fisik yang sesuai dapat diterapkan melalui berbagai keterampilan gerak dasar olahraga dalam bentuk permainan yang mendorong siswa untuk bergerak secara aktif. melalui pola-pola kegiatan permainan yang dimodifikasi siswa terlihat bergairah mengikuti berbagai permainan yang secara tidak disadari aktivitas gerak yang dilakukan para siswa tersebut dilakukan dengan optimal serta waktu aktif belajarnya pun tinggi, yang akhirnya berdampak pada peningkatan kebugaran jasmani para siswa tersebut (Rokhyati, Nur, Elan, \& Gandana, 2016).

Berdasarkan paparan di atas maka untuk meningkatkan kebugaran jasmanai siswa maka diperlukan peran aktif dari guru, orang tua dan masyarakat di daerah untuk membuat siswa melakukan berbagai aktifitas fisik dan olahraga, sehingga dapat meningkatkan kebugaran jasmani dan ketermpilan yang dimiliki oleh siswa tersebut. Kebugaran jamsni dapat ditingkatkan tidak hanya dengan aktifitas fisik saja, akan tetapi juga dapat dipengaruhi oleh faktor gizi dan lingkungan. (Khuddus, 2017) menjelaskan bahwa Beberapa faktor yang dapat mempengaruhi dan meningkatkan kebugaran jasmani yaitu makanan yang bergizi, aktivitas jasmani, pola hidup sehat, dan pola istirahat yang cukup.

Aktifitas fisik dan olahraga yang seusai dan menyenangkan mampu merangsang siswa untuk melakukan berbagai aktifitas olahraga, sehingga akan tertanam pada diiri siswa bahwa aktifitas fisik dan olahraga sangat penting bagi mereka untuk dapat mendukung prestasi belajar yang diharapkan. (Giriwijoyo, 2012) menjelakan bahwa manfaat lain dari kebugaran jasmani bagi tubuh antara lain dapat mencegah berbagai penyakit seperti jantung, pembuluh darah, dan paru-paru sehingga meningkatkan kualitas hidup secara keseluruhan. Guru dan orangtua serta masyarakat harus ikut serta dalam meningkatkan kebugaran jasmani siswa melalui aktifitas fisik dan olahraga dengan cara memberikan layanan pendidikn olahraga yang sesuai dan menyenangkan, ketersediaan fasilitas dan sarana olahraga yang mencukupi serta programprogram peningkatan keterampilan gerak untuk siswa SMP di daerah dataran tinggi Kabupaten Banyumas. 
Topo Suhartoyo ${ }^{1}$, Didik Rilastiyo Budi2, Moh. Nanang Himawan Kusuma ${ }^{3}$, Muhamad Syafei ${ }^{4}$, Arfin Deri Listiandi 5 , Rohman Hidayat ${ }^{6}$ PAJU : Physical Activity Journal 1 (1) (2019)

\section{SIMPULAN}

Berdasarkan hasil analisi data dan pembahasan dapat disimpulkan bahwa siswa SMP di daerah Kedungbanteng dan Baturraden yang terletak di wilayah datran tinggi/pegunungan Kabupten Banyumas memiliki tingkat kebugaran jasmani dengan kategori cukup untuk siswa putra dan kategori kurang untuk siswa putri. Apabila dibandingkan tingkat kebugaran jasmnai siswa putra dan putri di daerah dataran tinggi/pegunungan maka didapa hasil bahwa siswa putra memiliki nilai rata-rata kebugaran jasmani yang lebih baik daripada siswa putri. Hasil tersebut menunjukan bahwa tingkat kebugaran jasmani siswa SMP di daerah tersebut harus mendapatkan perhatian yang lebih, sehingga pada perkembangannya siswa tersebut mampu memiliki tingkat kebugaran jasmani yang baik, sebagai salah satu faktor pendukung untuk meningkatkan prestasi tidak hanya di olahraga tetapi juga prestasi belajar secara umum. Program pembelajaran pendidikan jasmani yang sesuai sangat dibutuhkan untuk meningkatkan peran aktif siswa dalam melakaukan berbagai aktifitas fisik dan olahraga. Aktifitas fisik dan olahraga harus diberikan dengan bentuk aktifitas multilateral yang menyenangkan sehingga mampu mendorong siswa untuk bergerak dan bergaya hidup aktif berolahraga yang pada tujuannya mampu meningkatkan kebugaran jasmani yang siswa.

Kebugran jasmani merupakan salah satu faktor utama bagi siwa untuk dapat meraih prestasi belajar, sehingga penting bagi guru, orangtua dan masyarakat menyediakan waktu yang cukup bagi siswa untuk berolahraga. Aktifitas olahraga yang dimaksud adalah aktifikas olahraga yang menyenangkan dan bukan yan monoton dan membosankan. Oleh karena itu aktifitas fisik dan olahraga harus diberikan dalam bentuk permainan yang menyenangkan.

\section{REFERENSI}

Budi, D. R., Hidayat, R., \& Febriani, A. R. (2019). The Application of Tactical Approaches in Learning Handballs. JUARA : Jurnal Olahraga. https://doi.org/10.33222/juara.v4i2.534

Budi, Didik Rilastiyo (2015) Pengaruh Modifikasi Permainan Vobas dan Kebugaran Jasmani Terhadap Peningkatan Kerjasama Siswa Dalam Pembelajaran Penjas Di SMP. S2 thesis, Universitas Pendidikan Indonesia

Giriwijoyo, S. dan D. Z. S. (2012). Ilmu Faal Olahraga (Fisiologi Olahraga). Bandung: Universitas Pendidikan Indonesia.

Hidayat, A. S. (2015). Hubungan Tingkat Kebugaran Jasmani Terhadap Prestasi Akademik ( Siswa Kelas Xi Perawat 2 SMK 10 November Sidoarjo). Jurnal Pendidikan Olahraga Dan Kesehatan, 3 (1).

Khuddus, L. A. (2017). Gangguan Perilaku Makan dan Tingkat Kecukupan Energi Protein Terhadap Kebugaran Jasmani Pemain Sepak Bola IKOR FIK UNESA. Jurnal Pembelajaran Olahraga, 3 (1).

Kusuma, M. N. H., Syafei, M., \& Rilastiyo, D. (2019). The Effect of Nutritional Status, Level of Physical Activity and Hemoglobins on Physical Endurance. JUARA : Jurnal Olahraga, 4(2), 186-195. https://doi.org/10.33222/juara.v4i2.607Maksum, A. (2012). Metode Penelitian. Surabaya: Unesa Press. 
Rokhyati, A., Nur, L., Elan, \& Gandana, G. (2016). Implementasi Pendekatan Taktis dalam Pembelajaran Pendidikan Jasmani Terhadap Motivasi, Kebugaran Jasmani dan Kemampuan Motorik. Jumal Pendidikan Jasmani Dan Olahraga, 1 (2).

Safaringga, E., \& Herpandika, R. P. (2018). Hubungan Kebugaran Jasmani dengan Kualitas Tidur. SPORTIF: Jurnal Penelitian Pembelajaran, 4 (2).

Sugiyono. (2015). Metodologi Penelitian Pendidikan. Bandung: CV. Alfabeta.

Wirnantika, I., Pratama, B. A., \& Hanief, Y. N. (2017). Survey Tingkat Kebugaran Jasmani Siswa Kelas IV SDN Puhrubuh I dan MI Mambaul Hikam di Kabupaten Kediri Tahun Ajaran 2016/2017. Jurnal Pembelajaran Olahraga, 3 (2). 